\title{
Manajemen Perilaku Organisasi Dalam Mewujudkan Sumber Daya Manusia Yang Kompeten
}

\author{
Abdu Darim \\ ${ }^{1}$ Pascasarjana Institut Pesantren Kh. Abdul Chalim Pacet Mojokerto \\ e-mail: abudarim.ikhac@gmail.com
}

Submitted: 01-01-2020 Revised : 15-02-2020 Accepted: 03-03-2020

\begin{abstract}
Penelitian ini dilakukan untuk memperoleh informasi tentang Manajemen Perilaku Organisasi Madrasah Pada Madrasah Ibtidaiyah (MI) Darussalam Pacet Tahun 2017/2018. Penelitian ini merumuskan bagaimana Manajemen perilaku organisasi madrasah pada MI Tahun 2017/2018 dalam mewujudkan sumber daya manusia, hambatan dan solusinya. Tujuan penelitian 1) mendeskripsikan manajemen perilaku organisasi madrasah pada MI Tahun 2017/2018 dalam mewujudkan sumber daya manusia. 2) Menganalisis hambatan dan solusi dalam penelitian ini.Hasil penelitian mengungkap mengenai (1) Manajemen Perilaku Organisasi Madrasah Pada Madrasah Ibtidaiyah (MI) Darussalam Pacet dalam mewujudkan sumber daya manusia yang dilakukan dengan perencanaan; dilaksanakan dengan melakukan analisis terhadap seluruh kegiatan atau beban pekerjaan kapasitas intelektual, kapabilitas, pengalaman kerjadan ketauladanan. Rekrutmen; mengutamakan prestasi akademik, non akademik, berakhlak baik,dan mengesampingkan hubungan kekerabatan serta mengutamakan prestasi dan profesionalisme. Pengembangan; mengubah perilaku agar terjadi perubahan danada peningkatan melalui workshop, diklat dan pelatihan. Pengawasan; dilakukan sesuai jadwal sebulan sekali pada seluruh rangkaian kegiatan sekolah, keadaan siswa, sarana prasarana, guru, program, fasilitas. Evaluasi; tiga tahap yaitu bulanan, tengah semester dan akhir semester, serta akhir tahun pembelajaran. Hambatan; Tenaga pengajar belum sesuai yang dibutuhkan, bukan lulusan pendidikan Guru, guru yang sudah mengajar tidak sesuai bidangnya, minimnya pengawasan, minimnya pengembangan kapasitas, dan kurangnya evaluasi. Solusi; manajemen rekrutmen dengan seleksi akademis dan non akademis, pengembangan guru pelatihan, worshop, pengawasan dan perhatian terhadap organisasi tersebut.
\end{abstract}

Keywords: Manajemen Perilaku Organisasi, Sumber daya Manusia, Guru Pendidikan Islam.

https:

How to Cite
Abu Darim. (2020). Manajemen Perilaku Organisasi Dalam Mewujudkan Sumber Daya Manusia Yang Kompeten. Munaddhomah: Jurnal Manajemen Pendidikan Islam, Volume 1 (1), 22-40.

\section{PENDAHULUAN}

Manajemen sebagai suatu system yang setiap komponennya menampilkan sesuatu untuk memenuhi kebutuhan. Dengan demikian, maka manajemen merupakan suatu proses untuk mencapai tujuan organisasi secara efektif danefisien (Rohmat, 2017:6).

Lembaga pendidikan yang memiliki sumber daya manusia yang berkualitas membutuhkan pembagian kerja yang proporsional dan penempatan para pekerja menurut kompetensinya masing-masing. Dengan demikian, setiap pelaku pendidikan memikul tanggung jawab penuh sesuai

Lembaga pendidikan dengan sistem kerja yang profesional, disamping menempatkan pelaku pendidikan yang sesuai dengan spesialisasinya, juga mengatur sistem gaji yang memiliki perbedaan yang adil, yaitu seimbang dengan beban kerja yang ditanggung oleh para pelaku 
pendidikan. Pembedaan besar gaji yang profesional diberlakukan secara sistematis dan formal sehingga para pelaku pendidikan akan meningkatkan prestasi kerjanya, terutama berhubungan dengan pengayaan ilmu penegetahuan dan pendalaman analisis ilmiah terhadap bidang studi yang diajarkan. Hal itu berkaitan dengan motivasi kerja dalam lembaga pendidikan (Akdon, 2009: 5).

Dalam sebuah organisasi, menurut Miftah Thoha bahwa kinerja atau perilaku seseorang dipengaruhi oleh berbagai faktor yang dapat dikelompokkan menjadi dua, yaitu faktor lingkungan individu dan faktor organisasi. Faktor individu meliputi: kemampuan, kebutuhan dan kepercayaan, pengalaman, penghargaan, dan sebagainya. Adapun faktor lingkungan organisasi meliputi tugastugas, wewenang, tanggung jawab, sistem pengendalian, kepemimpinan, dan sebagainya.

Thoha (2007:5) perilaku organisasi merupakan suatu studi yang menyangkut aspek-aspek tingkah laku manusia dalam suatu organisasi atau suatu kelompok tertentu. Selanjutnya, Duncan dalam Thoha (2007:5) hal-hal yang perlu dipertimbangkan dalam suatu perilaku organisasi adalah sebagai berikut: a) Studi perilaku organisasi termasuk didalamnya bagian-bagi an relevan dari semua ilmu tingkah laku yang berusaha menjelaskan. b) Tindakan-tindakan manusia didalam organisasi. c) Perilaku organisasi sebagaiman suatu disiplin ilmu mengenai bahwa individu dipengaruhi oleh bagaimana pekerjaan di atur ada siapa yang bertanggung jawab untuk pelaksanaannya. d) Walaupun dikenal adanya keunikan pada individu, namun perilaku organisasi masih memusatkan pada kebutuhan manajer untuk menjamin bahwa keseluruhan tugas pekerjaan yang bisa dijalankan.

Dalam konsep Perilaku organisasi menuntut pemahaman yang komplek tentang masingmasing individu dan kelompok, oleh karena itu seorang pemimpin tidak boleh memandang sebelah mata atau meremehkan sekecil apapun masalah yang terjadi dalam organisasi agar semua program dapat berjalan lancar, efektif dan efisien. Dengan demikian maka pembahasan ini perilaku sangat penting dalam mengawal pemahaman tentang organisasi (Achmad Mohyi, 1999:132).

Perilaku organisasi sering disingkat sebagai OB (Organisational Behavior), perilaku organisasi mempelajari tiga determinan perilaku dalam organisasi: perorangan (individu), kelompok dan struktur. Disamping itu, perilaku organisasi menerapkan pengetahuan yang diperoleh mengenai perorangan, kelompok dan efek dari struktur pada perilaku, agar organisasi bekerja dengan lebih efektif (Hasibuan,199). Dengan demikian, Organisasi sebagai sekelompok orang yang saling berinteraksi dan bekerjasama untuk merealisasikan tujuannya.

Oganisasi merupakan bagian yang tidak terpisahkan dengan kehidupan dan penghidupan manusia. Setiap hari manusia berhubungan dengan organisasinya.Walaupun pengalaman organisasi itu ada yang menyenangkan dan menjengkelkan, ada yang positif dan ada pula yang negatif, tetapi manusia tetap saja memerlukan organisasi (Didin Kurniadin dan Imam Machali, 2012). Organisasi sebagai arena perserikatan orang-orang yang beraktivitas, aktivitas orang-orang tersebut terarah kepada pencapaian tujuan.

Dalam menghadapi era globalisasi ini, organisasi perlu meningkatkan kinerjanya agar mampu bersaing dalam banyak konteks, yang bermakna bahwa kapasitas untuk 'berubah' dari sebuah organisasi penting sekali. Organisasi yang harus berubah adalah organisasi yang menggabungkan pembelajaran dalam tempat kerjanya. Upayanya berupa kualitas adaptasi dan aspek fundamental dimana individu harus melihat kedalam perubahan suatu paradigma. Dalam kontek ini individu haruslah merubah sikap atau dengan kata lain menyesuaikan perkembangan jaman karena individu dianggap sebagai penentu maju mundurnya suatu organisasi. Dikarenakan individu adalah segalanya bagi perkemban organisasi, mungkin bisa dikata bahwa organisasi tanpa individu adalah suatu kebohongan belaka atau tak mungkin. Dari hal ini maka kita lihat mengenai sebagian sifat dan pemikiran individu yang harus dimiliki demi terwujudnya suatu organisasi yang baik. Walaupun tanpa meniadakan komponen-komponen lain seperti teknologi. 
Pembangunan manusia seutuhnya merupakan cita - cita bangsa. Sumber Daya manusia (SDM) adalah sebagai modal dasar pembangunan yang terdiri atas dimensi kuantitatif yaitu jumlah dan struktur penduduk, serta dimensi kualitatif yaitu mutu hidup penduduk. Selain itu Sumber Daya Manusia juga merupakan kunci keberhasilan dalam menyelenggarakan suatu pembangunan guna memperlancar pencapaian sasaran pembangunan nasional antara lain kualitas manusia dan masyarakat Indonesia serta disiplin nasional yang merupakan perwujudan kepatuhan kepada hokum Negara dan norma- norma yang berlaku dalam masyarakat.

Negara dikatakan maju antara lain bila semakin tinggi tingkat pendidikan masyarakat, semakin tinggi tingkat kesehatan penduduk seperti misalnya tercermin dalam tingginya usia harapan hidup, serta semakin tinggi pendapatan pendudukdan semakin merata pendistribusiannya. $\mathrm{Hal}$ ini saling berkaitan, semakin tinggi tingkat pendapatan suatu keluarga, semakin mampu pula keluarga tersebut meningkatkan pendidikan anggota keluarganya serta menjaga kesehatannya. Disamping itu, dengan semakin tingginya tingkat pendidikan dan kesehatan, semakin tinggi pula produktifitas dan kemampuan untuk meningkatkan pendapatan. Selanjutnya bangsa dikatakan mandiri apabila bangsa tersebut mampu mewujudkan masyarakat yang berkehidupan layak, sejajar dan sederajad dengan bangsa lain dengan kekuatan sendiri. dengan terpenuhinya beberapa persyaratan antara lain meningkatnya Sumber daya manusia yang terlihat semakin banyak tenaga profesional yang mampu memenuhi tuntutan kebutuhan dan kemajuan pembangunannya.

Dengan demikian betapa pentingnya kualitas sumber daya manusia, baik secara tenaga penggerak atau pelaku pembangunan maupun sebagai tujuan dan sasaran pembangunan nasional. Sumber Daya Manusia sebagai inti pembangunan merupakan salah satu input (factor) yang menentukan keberhasilan pembangunan, maupun sebagai output atau yang ingin dihasilkan dari proses pembangunan nasional pada dasarnya peningkatan mutu pendididkan sudah sejak lama dibicarakan oleh para pelaku pembangunan dibidang pendidikan, tetapi realitas dan bukti empirik yang kita lihat dilapangan telah menunjukan bahwa mutu pendidikan di Indonesia masih dikatakan rendah. Karena itu dapat dikatakan bahwa sampai saat ini titik berat pembangunan pendidikan masih ditekankan pada upaya untuk peningkatan mutu.

Konsekuensi logis dari upaya peningkatan mutu pendidikan adalah perlunya peningkatan kwalitas secara keseluruan komponen system pendidikan, baik yang berupa sumber daya manusia maupun berupa sumber daya material. Dalam upaya peningkat mutu pendidikan, komponen pendidikan yang berupa sumber daya manusia (SDM) mempunyai peranan yang sangat penting dalam pencapaian tujuan yang diinginkan. Oleh karena itu para pimpinan lembaga pendidikan perlu memberikan perhatian yang serius terhadap pengelolaan sumber daya manusia yang terlibat didalamnya, bukan hanya guru, kepala sekolah dan karyawan tetapi juga para siswa,wali siswa dan masyarakat. Karena hanya dengan kesiapan SDM-lah yang akan mampu membawa lembaga pendidikan tetap susvive dan bias meningkatkan mutu pendidikan.

Dengan demikian Sumber Daya Manusia sebagai komponen pendidikan yang dianggap menjadi kunci keberhasilan pendidikan harus dibina dan dikembangkan secara kontinew sehingga menjadi Sumber Daya Manusia yang berkualitas mampu melaksanakan fungsinya secara professional. Karena Sumber Daya Manusia yang berkualitas dan professional merupakan kebutuhan mutlak dalam upaya peningkatan mutu pendidikan. Tetapi bagaimana pengelola Sumber Daya Manusia agar manusia dapat memegang peranan utama dan optimal dalam mewujudkan pendidikan yang berkualitas, bukanlah masalah yang sederhana. Ketidaksederhanaan ini dapat dilihat mencermati arti dari pengelolaan itu sendiri.

Disinilah pentingnya kepala sekolah sebagai menejer pendidikan perlu menggali, menyalurkan, membina dan mengembangkan potensi dan kemampuan yang dimiliki tenaga pendidik maupaun tenaga kependidikan dalam meningkatkan kualitas pendidikan. Disamping itu,menejer diharapkan, mampu menunjukkan efektifitasnya dalam mengelola Sumber Daya Manusia, terutama masalah kepegawaian dan hubungan antar pegawai. 
Walaupun secara konsep dikatakan Sumber Daya Manusia merupakan kunci keberhasilan pendidikan, namun dalam kenyataannya mereka kurang mendapat perhatian dari para menejer pendidikan. Rapat kerja, seminar, loka karya dan diskusi tentang pendidikan sebagian besar hanya membahas kurikulum saja terutama profesi belajar mengajar, tetapi sebagai mana caranya belajar mengajar dapat dilaksanakan oleh pelaksana pendidikan dengan baik tidak dapat mendapat perhatian. Hal dapat difahami dari kenyataan yang ada dilapangan bahwa masih banyaknya para menejer pendidikan yang masih mengabaikan aspek aspek pengelolaan Sumber Daya Manusia kurangnya perhatian para manajer pendidikan terhadap aspek pengelolaan Sumber Daya Manusia dapat dilihat dari system perencanaan Sumber Daya Manusia, system rekrutmen, seleksi dan penempatan, pelatihan dan pengembangan, maupun system kompensasi dan evaluasi Sumber Daya Manusia yang kurang tepat, sehingga mengakibatkan tidak sesuainya pekerjaan yang diberikan dengan disiplin ilmu yang dimiliki.

Disamping itu, masalah yang sering muncul dalam pengelolaan Sumber Daya Manusia adalah terjadinya kesenjangan kemampuan dan kecakapan para pelaksana pendidikan baik tenaga guru maupun nonguru, dengan tuntutan efektifitas dan efisiensi kerja, kurangnya para pelaksanan pendidikan menjalani orientasi dan memperoleh pendidikan yang konperhensif, serta kurangnya para pelaksana pendidikan yang terlatih dibanding dengan percepatan pembaharuan dalam bidang pendidikan.

Pada persoalan tentang rendahnya mutu pendidikan yang terjadi di Negara ini, secara makro bila dibandingkan dengan Negara-Negara lain, ternyata hal tersebut terjadi di semua jenjang pendidikan, mulai dari Pendidikan Dasar, Menengah dan Perguruan Tinggi, baik, yang dikelola Depdiknas maupun Departemen Agama. Yang lebih memprihatinkan lagi isu yang berkembang dimasyarakat bahwa mutu pendidikan yang dikelola Departemen Agama jauh dibawah mutu pendidikan yang dibawah naungan Depdiknas Selanjutnya, organisasi dalam segala hal dinilai sangat perlu bagi masyarakat. Dalam dunia industri, pendidikan, pelayanan kesehatan, dan pertahanan. Organisasi telah memberikan keuntungan yang mengesankan bagi standar hidup dan pandangan tentang dunia. Ukuran besarnya politik yang dihadapi setiap hari menggambarkan besarnya kekuasaan politik, ekonomi, dan sosial yang secara terpisah dimiliki organisasi tersebut (Baharuddindan umiarso, 2012).

Perilaku organisasi merupakan suatu aspek-aspek tingkah laku manusia dalam suatu organisasi atau suatu kelompok tertentu. Aspek yang ditimbulkan dari pengaruh organisasi terhadap manusia. Demikian pula aspek yang ditimbulkan dari pengaruh manusia terhadap organisasi. Tujuan praktis dari penelaahan mendeterminasi tentang perilaku manusia itu mempengaruhi usaha pencapaian tujuan-tujuan organisasi, termasuk organisasi sekolah. Organisasi sekolah yang juga sangat mengutakan sumberdaya manusia yang mumpuni dan profesional berdasarkan kualifikasinya. Kondisi seperti itu, diungkapkan manajemen perilaku organisasi sangat berperan penting dalam mewujudkan SDM yang berkualitas dan profesional sesuai dengan kapasitasnya.

MI berdiri 5 tahun, siswanya sudah melebihi proyeksi awal. Sehubungan dengan hal sebagaimana di paparkan di atas, maka dilakukan penelitian dengan judul Manajemen Perilaku Organisasi Madrasah pada MI Tahun 2017/2018

\section{KAJIAN LITERATUR}

Manajemen berasal dari bahasa Inggris yang merupakan terjemahan langsung dari kata management yang berarti pengelolaan, ketata laksanaan, atau tata pimpinan. Sementara dalam kamus Inggris Indonesia karangan John M.Echols dan Hasan Shadily (1995:372) management berasal dari akar kata to manage yang berarti mengurus, mengatur, melaksanakan, mengelola, dan memperlakukannya. 
Rohmat (2010:4) dalam modul mata kuliah Menejemen Mutu Terpadu dijelaskan bahwa menejemen adalah pemisahan antara perencanaan dan pelaksanaan yang mengakar pada tugas menejemen dan pelaksaan individu terampil dalam pekerjaan menghasilkan produk. Sementara manajemen menurut istilah adalah proses mengkordinasikan aktifitas-aktifitas kerja sehingga dapat selesai secara efesien dan efektif dengan dan melalui orang lain (Robbindan Coulter, 2007:8). Sedangkan Sondang P Siagian (1980: 5) mengartikan manajemen sebagai kemampuan atau keterampilan untuk memperoleh suatu hasil dalam rangka mencapai tujuan melalui kegiatankegiatan orang.

Bila kita perhatikan dari kedua pengertian manajemen diatas maka dapatlah disimpulkan bahwa manajemen merupakan sebuah proses pemanfaatan semua sumber daya melalui bantuan orang lain dan bekerjasama dengannya, agar tujuan bersama bisa dicapai secara efektif, efesien, dan produktip. Sedangkan Pendidikan Islam merupakan proses trans internalisasi nilai-nilaiIslam kepada peserta didik sebagai bekal untuk mencapai kebahagiaandan kesejahteraan di dunia dan di akhirat.

Dengan demikian maka yang disebut dengan manajemen pendidikan Islam sebagaimana dinyatakan Ramayulis (2008:260) adalah proses pemanfaatan semua sumber daya yang dimiliki (ummat Islam, lembaga pendidikan atau lainnya) baik perangkat keras maupun lunak. Pemanfaatan tersebut dilakukan melalui kerjasama dengan orang lain secara efektif, efisien, dan produktif untuk mencapai kebahagiaan dan kesejahteraan baik di dunia maupun di akhirat.

Dalam kamus besar bahasa Indonesia (1995:470), kata manajemen mempunyai persamaan arti atau sinonim dengan kata pengelolaan. Dalam Kamus Besar Bahasa Indonesia kata pengelolaan dapat diartikan sebagai (1) proses, cara, perbuatan mengelola; (2) proses melakukan kegiatan tertentu dengan menggerakkan tenaga orang lain; (3) proses yang membantu merumuskan kebijaksanaan dan tujuan organisasi; (4) proses yang memberikan pengawasan pada semua hal yang terlibat dalam pelaksanaan kebijaksanan dan pencapaian tujuan.

Adapun George R,Terry (1997:5), salah seorang pakar ilmu manajemen dalam bukunya Principles of Management mendefisinikan manajemen sebagai „,,... a distinct process consisting of planning, organizing, actuating, and controlling, performed to determine and accomplishstate objective bythe use ofhumanbeings and ather recauses".

Berdasarkan ketiga pengertian tersebut diatas maka dapat dikatakan bahwa kata manajemen merupakan hasil serapan dari kata management dalam bahasa Inggris yang mempunyai arti yang sama dengan kata pengelolaan. Menejemen adalah sebuah proses perdana ketika hendak melakukan pekerjaan baik dalam bentuk pemikiran maupun kerangka kerja agar tujuan yang hendak dicapai mendapatkan hasil yang optimal (Fattah, 1999: 22),

Menurut H.B. Siswanto (2005:2), mengemukakan bahwa pengertian manajemen adalah :

"Seni dan ilmu dalam perencanaan, pengorganisasian, pengarahan, pemotivasian, dan pengendalian terhadap orang dan mekanisme kerja untuk mencapai tujuan." berikut:

Sedangkan Menurut Henry Fayol (1949) Manajerial terdiri dari 5 fungsi, yaitu sebagai

1) (planning) berupa penentuan langkah-langkah yang memungkinkan organisasi mencapai tujuan-tujuannya.

2) Pengorganisasian (organizing), dalam arti mobilisasi bahan materiil dan sumber daya manusia guna melaksanakan rencana.

3) Memerintah (commanding) denganmemberiarahankepada karyawan agar dapat menunaikan tugas pekerjaan mereka 
4) Pengkoordinasian (coordinating) dengan memastikan sumber- sumber daya dan kegiatan organisasi berlangsung secara harmonis dalam mencapai tujuannya.

5) Pengendalian (controlling) dengan memantau rencana untuk membuktikan apakah rencana itu sudah dilaskanakan sebagaimana mestinya.

(George R.Terry, 2000:1). Menyebut manajemen sebagai sebuah proses yang khas yang terdiri dari tindakan-tindakan perencanaan, pengorganisasian, menggerakkan, pengarahandan pengawasan yang dilakukan untuk menentukan serta mencapai sasaran-sasaran yang telah ditetapkan melalui pemanfaatan sumber daya manusia serta sumber-sumber lain.

Menurut Hasibuan (2006;1) menegaskan bahwa manajemen adalah ilmu dan seni mengatur proses pemanfaatan sumber daya manusia dan sumber-sumber lainnya secara efektif dan efisien untuk mencapai suatu tujuan. Menurut Nanang Fatah (1988) Manajemen sebagai ilmu, yaitu bidang pengetahuan yang secara sistematik berusaha memahami mengapa dan bagaimana orang bekerja.

Sedangkan menurut Nunung Chosanah (1994) Manajemen adalah bagaimana cara mengatur, membimbing, dan memimpin semua orang yang menjadi bawahannya, agar usaha yang sedang dilaksanakannya dapat mencapai tujuan yang telah ditetapkan terlebih dahulu.

Manajemen merupakan pencapaian tujuan yang telah ditetapkan sebelumnya melalui usaha orang lain atau ada usaha-usaha untuk mencapai tujuan yang telah ditetapkan terlebih dahulu dengan mempergunakan kegiatan orang lain. Menurut AECT1977 membagi fungsi manajemen organisasi dan manajemen personalia sebagaimana dipraktekkan oleh administrator pusat dan program media. Manajemen melibatkan pengontrolan Teknologi Pembelajaran melalui perencanaan, organisasi, koordinasi, dan supervisi. Manajemen merupakan produk sistem nilai operasional. Kompleksitas manajemen sumber daya, personal dan desain, dan upaya pengembangannya teruntai dalam besarnya intervensi yang tumbuh dari departemen perusahaan atau departemen sebuah sekolah sampai intervensi pembelajaran berskala nasional dan multinasional global. Kesimpulan yang dapat diambil dari uraian diatas adalah manajemen memiliki banyak arti yang semuanya menunjukkan suatu kegiatan bersama. Selain itu ilmu manajemen dapat direalisasikan dalam semua aspek kehidupan. Begitu juga dengan manajemen proyek, dalam hal ini manajer proyek bertanggung jawab untuk merencanakan, menjadwal dan mengontrol fungsi-fungsi desain pembelajaran atau tipe proyek yang lain. Mereka harus melakukan negosiasi, pembiayaan, menetapkan sistem monitoring informasi dan mengevaluasi kemajuan.

Fungsi manajemen dapat diartikan sebagai kegiatan apa saja yang akan dilakukan oleh seorang manajer dalam kegiatan manajerialnya. Sehingga kegiatan manajerial yang dilakukan oleh manajer tersebut dapat dikatakan sebagai kegiatan proses manajemen. Proses tersebut bermuladari pembuatan perencanaan sampai pada pengadaan pengawasan terhadap pelaksanaan rencana tersebut. Pengawasan yang dilakukan bertujuan untuk mengetahui efektif atau tidaknya pelaksanaan rencanan sehingga tujuanyang telah ditetapkan dapat tercapai.

Fungsi-fungsi manajemen

Secara menyeluruh, fungsi manajemen tersebut adalah sebagai berikut

1) Perencanaan/Planning:

2) Pengorganisasian/Organizing:

3) Penyusunan Staf/Staffing:

4) Pengarahan/Directing :

5) Pengkoordinasian/Coordinating: Pengorganisasian mengandung hal-hal sebagai berikut: 
a) Sinkronisasi kegiatan

b) Keterpaduan kegiatan

c) Menyelaraskan kegiatan

d) Meruntutkankegiatan

e) Mencegah overlapingdan kekosongan kegiatan

6) Pelaksanaan. Pembagian tugas setiap kelompok agar terbentuk spesialisasi keahlian dan peningkatan hasil kerja. Organisasi diatur secara rasional, impersonal, bebas dari prasangka dengan karakteristik berikut:

a) Adanya pembagian tugas dan spesialisasi

b) Hubungan yang ada dalam organisasi didasarkan atas hubungan impersonal

c) Memiliki hirarki wewenang

d) Pembinaan pegawai (Rohmat, 2011:8)

7) Pengawasan/Controling:

Dari teori manajemen dan fungsi-fungsi pokok manajemen jika dikaitkan dengan kajian manajemen mutu pendidikan berbasis Teknologi Informasi dan Komunikasi, maka peran teori manajemen sangat dibutuhkan sekali. Dalam hal ini peneliti merujuk pada teory G. R Terry sebagai teori dasar karena Terry lebih menekankan pada pengorganisasian dan pelaksanaan dalam kegiatan manajemen di samping fungsi-fungsi manajemen yang lain. Selain Terry memasukkan proses evaluasi ke dalam fungsi pengawasan, hal ini berbeda dengan pendapat Henry Fayol yang memisahkan proses evaluasi dengan fungsi pengawasan.

Madrasah/Sekolah

Madrasah/Sekolah merupakan lembaga pendidikan dibawah naungan Kementrian Agama Republik Indonesia.

Pendidikan

Ki Hajar Dewantara menurutnya pendidikan adalah suatu tuntutan di dalam hidup tumbuh nya anak-anak. Maksudnya ialah bahwa pendidikan menuntun segala kekuatan kodrat yang ada pada peserta didik agar sebagai manusia dan anggota masyarakat dapat mencapai keselamatan dan kebahagiaan hidup yang setinggi- tingginya.

UU SISDIKNAS No. 20 tahun 2003: Pendidikan merupakan suatu usaha yang dilakukan secara sadar dan terencana untuk mewujudkan suasana dan proses pembelajaran agar peserta didik secara aktif mampu mengembangkan potensi yang ada didalam dirinya untuk memiliki kekuatan spiritual keagamaan, kepribadian yang baik, pengendalian diri, berakhlak mulia, kecerdasan,dan keterampilan yang diperlukan oleh dirinyadan masyarakat.

Menurut Ahmad D. Marimba (1989): Beliau juga berpendapat bahwa Pendidikan adalah"bimbingan atau pimpinan secara sadar oleh pendidik terdapat perkembangan jasmani dan rohani terdidik menuju terbentuknya kepribadian yang utama“.

Menurut Mashudi Bahari (2007) Pendidikan merupakan proses kompleks yang dipengaruhi oleh berbagai unsur termasuk kualitas pengajaran, kecerdasan, bakat dan minat siswa serta pengaruh motivasi, lingkungan sekolah, rumah dan dorongan orang tua terhadap siswa. Sedangkan menurut Martono. Lydia Harlina, dan Satya Joewana. (2006). Pendidikan merupakan salah satu aspek dari pendidikan yaitu aspek pengetahuan "kognitif" pengajaran memberikan ketrampilan dan pengetahuan, sedangkan pendidikan membimbing anak kearah kehidupan yang baik dan benar. Ada pula yang menegaskan yaitu Kamarudin Pendidikan merupakan suatu proses 
penanganan urusanu ntuk memungkinkan siswa mengetahui atau menyelesaikan sesuatu yang mereka menyelesaikan sesuatu yang mereka tidak dapat lakukan sendiri sebelum itu.

Ahmad D. Marimba Mengemukakan bahwa pendidikan ialah suatu proses bimbingan yang dilaksanakan secara sadar oleh pendidik terhadap suatu proses perkembangan jasmani dan rohani peserta didik, yang tujuannya agar kepribadian peserta didik terbetuk dengan sangat unggul. Kepribadian yang dimaksud ini bermakna cukup dalam yaitu pribadi yang tidak hanya pintar,pandai secara akademis saja, akan tetapi baik juga secara karakter.

Dari beberapa pengertian tersebut tentang definisi pendidikan, maka dapat disimpulkan bahwa pendidikan ialah bimbingan yang diberikan kepada anak dalam masa pertumbuhan dan perkembangannya untuk mencapai tingkat kedewasaan dan bertjuan untuk menambah ilmu pengetahuan, membentuk karakter diri,dan mengarahkan anak untuk menjadi pribadi yang lebih baik. Pendidikan juga bisa diartikan sebagai usaha sadar yang bertujuan untuk menyiapkan peserta didik dalam belajar melalui suatu kegiatan pengajaran, bimbingan dan latihan demi peranannya dimasa yang akan datang.

\section{Perilaku}

Perilaku manusia merupakan hasil daripada segala macam pengalaman serta interaksi manusia dengan lingkungannya yang terwujud dalam bentuk pengetahuan, sikap dan tindakan. Dengan kata lain, perilaku merupakan respon/reaksi seorang individu terhadap stimulus yang berasal dari luar maupun dari dalam dirinya. Respon ini dapat bersifat pasif (tanpa tindakan: berpikir, berpendapat, bersikap) maupun aktif (melakukan tindakan). Sesuai dengan batasan ini, perilaku kesehatan dapat dirumuskan sebagai bentuk pengalamandan interaksi individu dengan lingkungannya, khususnya yang menyangkut pengetahuan dan sikap tentang kesehatan. Allport (1954) mengemukakan perilaku adalah menunjukkan bahwa sikap itu tidak muncul seketika atau dibawa lahir, tetapi disusun dan dibentuk melalui pengalaman serta memberikan pengaruh langsung kepada respons seseorang.

Perilaku aktif dapatdilihat, sedangkan perilaku pasif tidak tampak, seperti pengetahuan, persepsi, atau motivasi. Menurut Sarwono (2004) membedakan bentuk-bentuk perilakuke dalam tiga domain yaitu pengetahuan, sikap, dan tindakan atau sering kita dengar dengan istilah knowledge, attitude, practice. Sedangkan dari sudut biologis, Notoadmodjo, (2003). Perilaku adalah suatu kegiatan atau aktivitas organisme yang bersangkutan, yang dapat diamati secara langsung maupun tidak langsung. Perilaku manusia adalah suatu aktivitas manusia itu sendiri Ensiklopedi Amerika, perilaku diartikan sebagai suatu aksi-reaksi organisme terhadap lingkungannya. Perilaku baru terjadi apabila ada sesuatu yang diperlukan untuk menimbulkan reaksi, yakni yang disebut rangsangan. Berarti rangsangan tertentu akan menghasilkan reaksi atau perilaku tertentu (Notoadmodjo, 2003)

Notoatmodjo, (2007) mengemukakan perilaku adalah tindakan atau aktivitas dari manusia itu sendiri yang mempunyai bentangan yang sangat luas antara lain: berjalan, berbicara, menangis, tertawa, bekerja, kuliah, menulis, membaca, dan sebagainya. Dari uraian ini dapat disimpulkan bahwa yang dimaksud perilaku manusia adalah semua kegiatan atau aktivitas manusia, baik yang diamati langsung, maupun yang tidak dapat diamati oleh pihak luar Menurut Skinner, merumuskan bahwa perilaku merupakan respon atau reaksi seseorang terhadap stimulus atau rangsangan dari luar. Oleh karena perilaku ini terjadi melalui proses adanya stimulus terhadap manusia, dan kemudian manusia tersebut merespons.

Proses Pembentukan Perilaku

Perilaku manusia terbentuk karena adanya kebutuhan. Menurut Abraham Harold Maslow,manusia memiliki lima kebutuhan dasar pembentuk perilaku,yakni : 
1) Kebutuhan fisiologis/biologis, yang merupakan kebutuhan pokok utama, yaitu H2, $\mathrm{H} 2 \mathrm{O}$, cairan elektrolit, makanan dan seks. Apabila kebutuhan ini tidak terpenuhiakan terjadi ketidakseimbangan fisiologis. Misalnya, kekurangan yang menimbulkan sesak nafas dan kekurangan $\mathrm{H} 2 \mathrm{O}$ dan elektrolit yang menyebabkan dehidrasi.

2) Kebutuhan rasa aman, misalnya :Rasa aman terhindar dari pencurian, penodongan, perampokan dan kejahatanlain. Rasa aman terhindar dari konflik, tawuran, kerusuhan, peperangandan lain-lain. Rasa aman terhindar dari sakit dan penyakit dan Rasa aman memperoleh perlindungan hukum.

3) Kebutuhan mencintai dan dicintai Mendambakan kasih sayang/cinta kasih orang lain baik dari orang tua, saudara, teman, kekasih, dan lain-lain. Ingin dicintai/mencintai orang lain, ingin diterima oleh kelompok tempat ia berada.

4) Kebutuhan harga diri, misalnya: Ingin dihargai dan menghargai orang lain, Adanya respek atau perhatian dari oranglain.

5) Kebutuhan aktualisasi diri, misalnya : Ingin dipuja atau disanjung oleh orang lain, ingin sukses atau berhasil dalam mencapai cita- cita, ingin menonjol dan lebih dari orang lain, baik dalam karier, usaha, kekayaan, dan lain-lain.

\section{Organisasi}

F. Stoner (1996) mengemukakan organisasi adalah suatu polahubungan-hubungan yang melalui mana orang-orang dibawah pengarahan manajer mengejar tujuan bersama. Sedangkan Menurut James D. Mooney (1996) organisasi adalah bentuk setiap perserikatan manusia untuk mencapai tujuan bersama.

Menurut Chester I. Bernard (1992) organisasi merupakan suatu sistemaktivitas kerjasama yang dilakukan oleh dua orang atau lebih. Menurut Louis A. Allen (1958) Organisasi dapat diartikan sebagai proses penentuan dan pengelompokan pekerjaan yang akan dikerjakan, menetapkan dan melimpahkan wewenang dan tanggung jawab, dengan maksud untuk memungkinkan orang-orang bekerja sama secara efektif dalam mencapai tujuan.

John M. Pfifner dan Frank P. Sherwood (1958) Organisasi adalah pola keadaan dimana sejumlah orang banyak, sangat banyak mempunyai teman berhubungan langsung dengan semua yanglain, dan menangani tugas-tugas yang kompleks, menghubungkan mereka sendiri satu sama lain dengan sadar, penentuan dan pencapaian yang sistematis dari tujuan-tujuan yang saling disetujui.

Banyak macam dan ragam bentuk suatu organisasi mulai dari yang berbentuk kecil hingga organisasi yang bentuknya besar dan mempunyai suatu tujuan yang berbeda pula, begitu pula tentang pengertian organisasi itu sendiri. Banyak definisi dan pengertian dari organisasi yang di paparkan oleh para ahli, berikut adalah beberapa definisi dan pengertian dari Organisasi : penyusunan dan pengaturan bagian-bagian hingga menjadisuatu kesatuan; sususan danaturandari berbagaibagian sehingga merupakan kesatuan yang teratur; gabungan kerja sama (untuk mencapai tujuan tertentu).

Organisasi adalah suatu kelompok orang yang memiliki tujuan yang sama. Baik dalam penggunaan sehari-hari mau pun ilmiah, istilah ini digunakan dengan banyak cara. Organisasi adalah bentuk formal dari sekelompok manusia dengan tujuan individual nya masing-masing (gaji, kepuasan kerja, dll) yang bekerjasama dalam suatu proses tertentu untuk mencapai tujuan bersama (tujuan organisasi). Agar tujuan organisasi dan tujuan individu dapat tercapai secara selaras dan harmonis maka diperlukan kerjasama dan usaha yang sungguh-sungguh dari kedua belah pihak (pengurus organisasi dan anggota organisasi) untuk bersama-sama berusaha saling memenuhi kewajiban masing-masing secara bertanggung jawab, sehingga pada saat masing-masing 
mendapatkan haknya dapat memenuhi rasa keadilan baik bagi anggota organisasi / pegawai maupun bagi pengurus organisasi / pejabat yang berwenang.

Organisasi adalah sistem hubungan yang terstruktur yang mengkoordinasikan usaha suatu kelompok orang untuk mencapai tujuan. Organisasi adalah suatu bentuk sistem terbuka dari aktivitas yang dikoordinasi oleh dua orang atau lebih untuk mencapai tujuan bersama. yakni:

Dalam hal ini beberapa definisi yang menjadi titik tolak dalam uraian-uraian selanjutnya,

1) Organisasi adalah sebuah unit sosial yang dikoordinasikan secara sadar, terdiri atas dua orang atau lebih dan yang relatif terus-menerus guna mencapai satu atau serangkaian tujuan bersama (Robbins dan Judge, 2008:5).

2) Organisasi adalah suatu wadah yang dibentuk untuk mencapai tujuan bersama secara efektif (Wibowo, 2007:1)

3) Organisasi adalah suatu sistem perserikatan formal, berstruktur, dan terkoordinasi dari sekelompok orang yang bekerja sama dalam mencapai tujuan tertentu. Organisasi hanya merupakan alat dan wadah saja (Hasibuan,2004:120).

Berdasarkan ciri tersebut dapat dirumuskan definisi organisasi yaitu suatu wadah yang terdiri dari kumpulan orang yang terikat dengan hubungan-hubungan formal dalam rangkaian terstruktur untuk mencapai tujuan bersama secara efektif

Unsur-unsur organsasi

Setiap bentuk organisasia kan mempunyai unsur-unsur tertentu, yang antara lain sebagaiberikut:

Man

Man (orang-orang), dalam kehidupan organisasi atau ketatalembagaan sering disebut dengan istilah pegawai atau personnel. Pegawai atau personnel terdiri dari semua anggota atau warga organisasi, yang menurut fungsi dan tingkatannya terdiri dari unsur pimpinan (administrator) sebagai unsure pimpinan tertinggi dalam organisasi, para manajer yang memimpin suatu unit satuan kerja sesuai dengan fungsinya masing-masing dan para pekerja (non management/workers). Semua itu secara bersama-sama merupakan kekuatan manusiawi (man power) organisasi.

Kerjasama

Kerjasama merupakan suatu perbuatan bantu-membantu akan suatu perbuatan yang dilakukan secara bersama-sama untuk mencapai tujuan bersama. Oleh karena itu, semua anggota atau semua warga yang menurut tingkatan-tingkatannya dibedakan menjadi administrator, manajer, dan pekerja (workers), secara bersama-sama merupakan kekuatan manusiawi (manpower) organisasi.

\section{Tujuan Bersama}

Tujuan merupakan arah atau sasaran yang dicapai. Tujuan menggambarkan tentang apa yang akan dicapai atau yang diharapkan. Tujuan merupakan titik akhir tentang apa yang harus dikerjakan. Tujuan juga menggambarkan tentang apa yang harus dicapai melalui prosedur, program, pola (network).

Peralatan (Equipment)

Unsur yang keempat adalah peralatan atau equipment yang terdiri dari semua sarana, berupa materi, mesin-mesin, uang, dan barang modal lainnya (tanah, gedung/bangunan/kantor).

Lingkungan (Environment) 
Faktor lingkungan misalnya keadaan sosial, budaya, ekonomi, dan teknologi. Kebijaksanaan (policy), strategi, anggaran (budgeting), dan peraturan-peraturan (regulation) yang telah ditetapkan. Dan juga beberapa tujuan tertentu.

SumberDayaManusia (SDM)

Pengertian sumber daya manusia dan penerapannya sering kali masih belum sejalan dengan keinginan organisasi. Sementara keselarasan dalam mengelola SDM menjadi faktor utama kesuksesan jalannya sebuah organisasi. Pada hakikaktnya, SDM atau Sumber Daya Manusia adalah orang-orang yang dipekerjakan disuatu organisasi yang nanti nyaakan menjadi penggerak untuk bisa mencapai tujuan organisasi itu sendiri.

Sonny Sumarsono (2003:4), Sumber Daya Manusia atau human recources mengandung dua pengertian. Pertama, adalah usaha kerja atau jasa yang dapat diberikan dalam proses produksi. Dalam hal lain SDM mencerminkan kualitas usaha yang diberikan oleh seseorang dalam waktu tertentu untuk menghasilkan barang dan jasa. Pengertian kedua, SDM menyangkut manusia yang mampu bekerja untuk memberikan jasa atau usaha kerja tersebut. Mampu bekerja berarti mampu melakukan kegiatan yang mempunyai kegiatan ekonomis, yaitu bahwa kegiatan tersebut menghasilkan barang atau jasa untuk memenuhi kebutuhan atau masyarakat.

Mary Parker Follett Manajemen Sumber Daya Manusia adalah suatu seni untuk mencapai tujuan-tujuan organisasi melalui pengaturan orang-orang lain untuk melaksanakan berbagai pekerjaan yang diperlukan, atau dengan kata lain tidak melakukan pekerjaan-pekerjaan itu sendiri.

Manajemen memang dapat mempunyai pengertian lebih luas dari pada itu, tetapi definisi diatas memberikan kepada kita kenyataan bahwa kita terutama mengelola sumber daya manusia bukanmaterialatau finansial. Dilain pihak manajemen mencakup fungsi-fungsi perencanaan (penetapan apa yang akan dilakukan), pengorganisasian (perencanaan dan penugasan kelompok kerja), penyusunan personalia (penarikan, seleksi, pengembangan, pemberian kompensasi, dan penilaian prestasi kerja), pengarahan (motivasi, kepemimpinan, integrasi,dan pengelolaan konflik) dan pengawasan.

M.T.E. Hariandja (2002:2) Sumber Daya Manusia merupakan salah satu faktor yang sangat penting dalam suatu perusahaan disamping faktor yang lain seperti modal. Oleh karena itu SDM harus dikelola dengan baik untuk meningkatkan efektivitas dan efisiensi organisasi.

Mathis dan Jackson (2006: 3) SDM adalah rancangan sistem- sistem formal dalam sebuah organisasi untuk memastikan penggunaan bakat manusiasecara efektif dan efisien guna mencapai tujuan organisasi.

Demikian pula menurut The Chartered Institute of Personneland Development (CIPD) dalam Mullins (2005). Sumber daya manusia dinyatakan sebagai strategi perancangan, pelaksanaan dan pemeliharaan untuk mengelola manusia untuk kinerja usaha yang optimal termasuk kebijakan pengembangan dan proses untuk mendukung strategi.

Hasibuan (2003:244) Pengertian Sumber Daya Manusia adalah kemampuan terpadu dari daya piker dan daya fisik yang dimiliki individu. Pelaku dan sifatnya dilakukan oleh keturunan dan lingkungannya, sedangkan prestasi kerjanya dimotivasi oleh keinginan untuk memenuhi kepuasannya.

Menurut Aburrahmat Fathoni (2006) sumber daya manusia merupakan modal dan kekayaan terpenting dalam setiap aktivitas ataupun kegiatan manusia. Untuk bias mencapai tujuan yang telah ditetapkan, manusia perlu dianalisis dan dikembangkan dengan cara yang sesuai yang memperhatikan unsur-unsure berupa waktu, kemampuan, dan tenaga yang dimilikioleh setiap individu sumber daya manusia. 
SDM terdiri dari daya fikir dan daya fisik setiap manusia. Tegasnya kemampuan setiap manusia ditentukan oleh daya fikir dan daya fisiknya. SDM atau manusia menjadi unsur utama dalam setiap aktivitas yang dilakukan. Peralatan yang handal atau canggih tanpa peran aktif SDM, tidak berarti apa-apa. Daya pikir adalah kecerdasan yang dibawa sejak lahir (modal dasar) sedangkan kecakapan diperoleh dari usaha (belajar dan pelatihan). Kecerdasan tolok ukurnya Intelegence Quotient (IQ) dan Emotion Quality (EQ)

Sumber daya manusia (SDM) harus kreatif. Dalam perspektif Islam, kreatif dapat diartikan sebagai kesadaran keimanan seseorang, untuk menggunakan keseluruhan daya dan kemampuan diri yang dimiliki sebagai wujud syukur akan nikmat Allah, guna menghasilkan sesuatu yang terbaik dan bermanfaat bagi kehidupan sebagai wujud pengabdian yang tulus kepadaAllah (Rohmat, 2017:121).

Manajemen perilaku organisasi pendidikan

Manajemen sebagai sebuah proses yang khas yang terdiri dari tindakan-tindakan perencanaan, pengorganisasian, menggerakkan, pengarahan dan pengawasan yang dilakukan untuk menentukan serta mencapai sasaran-sasaran yang telah ditetapkan melalui pemanfaatan sumber daya manusia serta sumber-sumber lain. Perilaku adalah suatu kegiatan atau aktivitas organisme yang bersangkutan, yang dapat diamati secara langsung maupun tidak langsung. Organisasi adalah pola keadaan dimana sejumlah orang banyak, sangat banyak mempunyai teman berhubungan langsung dengan semua yang lain, dan menangani tugas- tugas yang kompleks, menghubungkan mereka sendiri satu sama lain dengan sadar, penentuan dan pencapaian yang sistematis dari tujuantujuan yang saling disetujui.

Gambaran konseptual tentang pendidikan yang berwawasan masa depan secara operasional berkaitan dengan seluruh proses pengelolaan lembaga pendidikan, yaitu:

a. konsep tentang penjaringan dan seleksi siswa/mahasiswa

b. desain dan pengembangan kurikulum

c. penjaringan dan penempatan guru/dosen

d. pengadaan dan pengayaan kepustakaan yang relevan dengan visi dan misi lembaga pendidikan

pemberdayaan pejabat structural dan fungsional yang sinergis dengan keahliannya(Akdon danHikmat, 2011:50).

\section{METODE PENELITIAN}

Metode yang digunakan penulis dalam penelitian ini adalah pendekatan penelitian kualitatif. Moleong, (2012:6) mengemukakan Penelitian kualitatif adalah penelitian yang bermaksud untuk memahami fenomena tentang apa yang dialami oleh subyek penelitian misalnya perilaku, persepsi, dan persoalan tentang manusia yang diteliti, dan lain-lain.

Pendekatan penelitian kualitatif ini, untuk melakukan penelitian yang berkaitan dengan manajemen perilaku organisasi pendidikan mewujudkan SDM pada MI tahun 2016. Penelitianya itu diskriptif kualitatif. Arikunto (2002:206) berpendapat bahwa pada umumnya penelitian deskriptif merupakan penelitian non hipotesa, sehingga dalam rangka penelitiannya tidak perlu merumuskan hipotesis.

\section{Subjek dan Informan Penelitian}

Subjek penelitian dalam penelitian ini adalah Kepala Sekolah di MI Darussalam Pacet Tahun 2016. Sedangkan informan dalam penelitian ini adalah Guru, siswa, wakil kepala bidang kurikulum dan pengawas Sekolah. 
Sumber data utama dalam penelitian kualitatif ialah kata-kata dan tindakan (Moloeng, 2012:157). Dapat ditarik kesimpulan bahwa sumber data dalam penelitian ini adalah subjek dimana data dapat diperoleh.Sumber data dalam penelitian ini adalah perilaku,tindakan, peristiwa, ucapanucapan hasil wawancara, dokumen dan interaksi guru-guru beserta para peserta didik MI.

Metode Pengumpulan Data

Metode pengumpulan data yang digunakan dalam penelitian ini, penulis menggunakan metode observasi, wawancara dan dokumen.

\section{Observasi}

Metode Observasi adalah suatu metode yang digunakan dalam pengamatan dan pencatatan data secara sistematis terhadap fenomena- fenomena yang diselidiki. Observasi atau disebut pula dengan pengamatan meliputi penglihatan, penciuman, pendengaran, peraba dan pengecap (Arikunto, 2002: 133)

Metode ini digunakan untuk mengumpulkan data-data dari lapangan dengan jalan menjadi partisipan secara langsung di MI Darussalam Pacet untuk mengetahui manajemen perilaku organisasi pendidikan mewujudkan Sumber Daya Manusia.

\section{Wawancara}

Wawancara merupakan metode pengumpulan data dengan jalan tanya jawab antaran dua orang atau lebih bertatap muka dan mendengarkan secara langsung tentang informasiinformasi yang diberikan. Selain dilakukan secara langsung wawancara juga dapat menggunakan telepon (Sugiyono, $2013: 138$ )

Wawancara adalah percakapan dengan maksud tertentu. Percakapan ini dilakukan oleh dua pihak, yaitu pewawancara yang mengajukan pertanyaan dan yang diwawancarai yang memberikan jawaban atas pertanyaan (Moloeng, 2012 : 186) Wawancara yang dilakukan kepada para guru-guru, wakil kepala sekolah bidang kurikulum, siswa dan pengawas sekolah untuk mengetahui hal-hal sebagai berikut:

a. Manajemen Perilaku organisasi madrasah pada MI, mewujudkan sumber daya manusia yang dilakukan oleh kepala sekolah

b. Strategi manajemen perilaku organisasi pendidikan yang dijalankan dan segala yang terkait.

\section{Dokumentasi}

Pada pelaksanaan metode dokumentasi, peneliti menyelidiki benda-benda tertulis seperti buku-buku, majalah, dokumen, peraturan- peraturan, notulen rapat, catatan harian dan sebagainya. Metode dokumentasi sebagai metode pengumpulan data memiliki posisi yang sangat penting dalam penelitian kualitatif (Moloeng, 2012:218)

Pemeriksaan Keabsahan Data

Pada penelitian ini peneliti dalam mencari validitas atau keabsahan data menggunakan teknik triangulasi data dan perpanjangan keikutsertaan triangulasi adalah teknik pemeriksaan keabsahan data yang memanfaatkan sesuatu yang lain diluar data itu untuk keperluan pengecekan atau perbandingan terhadap data itu. (Moleong, 2008: 330)

Teknik triangulasi data yang digunakan dalam penelitian ini adalah teknik triangulasi dengan sumber, yaitu, membandingkan dan mengecek balik derajat kepercayaan suatu informasi yang diperoleh. (Moleong, 2008: 331)

Perpanjangan keikut sertaan maksudnya untuk memperoleh data pada penelitian ini, selalu ada proses keikutsertaan dalam kegiatan yang diteliti. Keikut sertaan dalam penelitian sangat 
menentukan keakuratan pengumpulan data. Keikutsertaan tersebut tidak hanya dilakukan dalam waktu singkat, namun membutuhkan waktu yang lama, sehingga dalam melakukan penelitian ini memang selalu mengikuti proses/kegiatan tersebut. Dalam hal ini peneliti dalam melakukan pengamatan sering mengikuti kegiatan atau program dari kelompok kerja kepala sekolah guna mendapatkan data ataupun informasi yang maksimal.

\section{Teknik Analisis Data}

Analisis data adalah proses mengatur urutan data,mengorganisasikannya ke dalam suatu pola, dan satuan uraian dasar (Moleong,2000:103). Dalam pelaksanaannya, analisis data kualitatif bertujuan pada proses penggalian makna, penggambaran, penjelasan dan penempatan data pada konteknya masing-masing (Arikunto, 2008:126). Pelaksanaan analisis data dilakukan pada saat pelaku riset masih dilapangan dan setelah data terkumpul. Hal ini terkait dengan kepentingan memperbaiki data dan atau mengubah, baik asumsi teoritik yang digunakan maupun pertanyaan yang menjadi focusriset. (Ali, 2011: 248)

Penelitian kualitatif berusaha mengungkapkan gejala secara menyeluruh dan sesuai dengan konteks melalui pengumpulan data dari latar alami dengan memanfaatkan diri peneliti sebagai instrumen kunci (Pedoman Tesis dan Disertasi UNY, 2004:19). Pada penelitian ini analisis data dilakukan bersamaan dengan pengumpulan data dan dilanjutkan setelah kembali dari lapangan. Hasil analisis sementara akan selalu dikonfirmasikan dengan data baru yang diperoleh dari sumber-sumber lain yang memiliki tingkat kepercayaan lebih akurat baik diperoleh melalui wawancara, observasi maupun dokumentasi. Disisi lain pemanfaatan teori yang relevan dipakai sebagai pisau analisis data kualitatif akan menghasilkan analisis deskriptif yang berbobot dan memiliki makna mendalam.

Data-data yang sudah terkumpul dari hasil wawancara, observasi dan dokumentasi, kemudian dianalisis berdasarkan model analisis interaktif yang dikembangkan oleh Miles dan Huberman. Ada empat komponen yang dilakukan dengan model ini, yaitu pengumpulan data, reduksi data, display data dan penarikan kesimpulan. (Miles dan Huberman, 1994: 23)

\section{HASIL DAN PEMBAHASAN}

Pelaksanaan Manajemen perilaku organisasi madrasah pada MI Tahun 2017/2018.

Pembahasan temuan hasil penelitian di MI Darussalam Pacet yang penulis sajikan berdasarkan hasil wawancara, dokumentasi dan observasi yang dilakukan secara formal maupun tidak formal. Wawancara secara formal dan tidak formal, observasi dan pencermatan dokumentasi dilakukan langsung oleh peneliti. Adapun pembahasan temuan hasil penelitian sebagaimanaberikut

Perencanaan SDM juga dilakukan melalui beberapa tahapan seperti membuat tupoksinya (Tugas pokok dan fungsi) terlebih dahulu dalam arti beban kerjanya seperti apa, baru kemudian mencari dan memilih personil yang tepat untuk melakukan tugas tersebut. Dalam melakukan pengisian personil, disamping berdasarkan kapasitas intelektual, kapabilitas dan pengalaman, juga mempertimbangkan prestasi akademik dan keterampilan.

Analisis pekerjaan dan jabatan tersebut selama ini dilaksanakan melalui beberapa tahapan, Antara lain: (1) pembuatan draft atau rancangan oleh kepala sekolah dengan tim yang ditunjuk, (2) pembahasan dalam rapat pleno, (3) rapat/siding pleno, (4) pembuatan dan penetapan SK. (wawancara dengan MD) apa yang disampaikan benar bahwa" pertimbangan yang dijadikan dasar dalam melakukan analisis pekerjaan Antara lain jumlah siswa, jumlah kegiatan dan program yang harus disesuaikan, disamping itu perlu tambahan dukungan sarana prasarana serta kekuatan finansial dalam rangka mencapai tujuan ". 
Adapun draft atau konsep awal tentang analisis pekerjaan yang mencerminkan tugas pokok dan fungsi semua komponen sekolah, mulai dari kepala sekolah hingga level paling bawah tidak semata mata dirumuskan atau disusun oleh kepala sekolah secara pihak tetapi dirumuskan dan disusun oleh tim yang dibentuk tersebut.

Manajemen Rekrutmen, seleksi dan Penempatan Sumber Daya Manusia

Rekrutmen guru, pegawai atau karyawan baru bagi sebuah organisasi selalu menjadi sebuah tantangan tersendiri bagi organisasi tersebut, termasuk didalamnya adalah lembaga pendidikan. Kegiatan ini merupakan kelanjutan dari perencanaan SDM, biasanya kebutuhan SDM ini diketahui secara pasti setelah sebelumnya dilakukan analisis dalam perencanaan. Namun terkadanng tidak sedikit pula organisasi dihadapkan pada permintaan yang mendadak untuk mengisi kekosongan secara cepat dan tepat karena kondisi diluar perencanaan, suatu contoh, ketika pada suatu saat ditengah tengah semester ada guru yang diangkat menjadi PNS dan ditempatkan disekolah lain, maka harus secepatnya diisi kekosongan tersebut. Dan apapun alasanya terjadinya kekosongan dalam sebuah organisasi, yang jelas hal tersebut harus segera diisi dan diselesaikan.

Dari penelitian yang dilakukan didapatkan bahwa proses rekrutmen dan seleksi calon guru dan pegawai atau karyawan di MI dilaksanakan melalui beberapa tahapan: (1) Melihat formasi yang dibutuhkan, (2) menyampaikan pengumuman, (3) Melakukan pemanggilan, (4) wawancara dan (5) penerimaan dan penempatan.

Kriteria prestasi akademik dan non akademik juga merupakan standar yang berlaku bagi semua pelamar baik pelamar umum maupun pelamar yang masih mempunyai hubungan kekerabatan dengan pihak kepala sekolah, guru bahkan dinas pendidikan kecamatan.

Adapun penempatan guru yang sudah lolos seleksi, hal ini dilakukan melalui dua model, yaitu: Pertama, dengan cara penempatan secara langsung yang biasanya diterapkan untuk rekrutmen guru. Kedua, dengan cara melalui pemagangan, dimana hal ini biasanya diterapkan dalam rekrutmen calon guru.

Pelatihan dan Pengembangan Sumber Daya

Adapun beberapa program-progran dan bentuk pelatihan yang sudah dilaksanakan di MI Darussalam Pacet pada akhir akhir ini adalah pelatihan profesi guru, KTSP, KK13, komputer, perpustakaan dan lain lain. Masih ada pelatihan yang lain diantarannya pelatihan calon kepala sekolah bagi yang berminat mencalonkan diri untuk menjadi kepala sekolah tentunya dengan persyaratan yang telah dittentukan. Disamping melakukan pelatihan dilingkkungan lembaga sendiri, MI juga mengikut sertakan para guru dan karyawan mengikuti pelatihan diluar lembaga sesuai dengan undangan. Baik ditingkat Kabupaten atau propinsi, bahkan sampai tinngkat nasional.

Manajemen Evaluasi Sumber Daya Manusia.

Sistem evaluasi SDM atau sering dikenal dengan penilaian kinerja merupakan kegiatan mengukur atau menilai apakah untuk seorang guru atau karyawan itu sukses atau gagal dalam melaksanakan pekerjaanya dengan menggunakan standar pekerjaan sebagai tolok ukur.

Sistem evaluasi ini setidaknya bertujuan: Pertama, untuk memberikan dasar bagi rencana dan pelaksanaan pemberian penghargaan bagi guru dan karyawan atas kinerja mereka pada periode waktu sebelumnya (toreward past performance), dan kedua, untuk memotivasi agar pada waktu yang akan datang kinerja guru dan karyawan tersebut bias lebih ditingkatkan (tomotivate future performance improvement).

Sistem evaluasi yang dilakukan di MI Darussalam Pacet melalui cara, yaitu: Pertama, evaluasi bulanan yang dilakukan untuk mengevaluasi perjalanan program sekolah selama satu bulan dan melakukan penyerapan terhadap kasus-kasus yang ada dilapanngan,baik kegiatan KBM, 
kasus siswa. Kedua, rapat evaluasi tengah tahun atau akhir semester. Ketiga, rapat evaluasi akhir tahun pembelajaran hal ini dilakukan untuk mengevaluasi perjalanan sekolah selama satu tahun. Hasilnya akan digunakan pedoman pembuatan RAKS dan RAPBS berikutnya.

Selain evaluasi evaluasi tersebut masih juga dilakukan evaluasi yang sifatnya isi dental dengan study kasus yang segera diselesaikan. Evaluasi para pelaksana program kerja tersebut berlaku umum, dalam arti diberlakukan sama pada guru dan karyawan. karena pada dasarnya semua ikut memberikan kontribusi terhadap keberhasilan proses belajar mengajar di sekolah. Kriteria atau tolok ukur yang dijadikan sebagai pembanding dalam menentukan kegagalan dan keberhasilan seorang guru maupun karyawan dalam melaksanakan tugasnya menggunakan tupoksi sebagai standar pekerjaan utama di samping beberapa factor pendukung lain.

Khusus PNS baik guru atau karyawan dalam pelaksanaan penilaian disamping mengggunakan tupoksi sebagaimana tersebut diatas dan beberapa faktor pendukung lainnya, antara lain DP3, sebuah alat evaluasi kinerja guru yang dibuat dari pemerintah pusat, yang berlaku untuk semua instansi di semua level. DP3 yang merupaka alat evaluasi kinerja guru kurang evaluative karena tidak mendasar pada standar pekerjaan, dan standar pekerjaan selalu berbeda beda. Adanya PKG (Penilaian Kinerja Guru) dengan menggunakan DP3 sudah sesuai dengan standar pekerjaan. Dengan alasan berdasarkan kinerja yang beda dan telah dilaksanakan pemantauan secara terus menerus, dan penilaian tersebut merupakan sebuah keharusan, tanpa ada penilaian tidak ada yang baik dan yang buruk.

\section{Sistem Pengawasan}

Sistem manajemen pengawasan atau control pada dasarnya merupakan upaya member petunjuk para pelaksana program agar dalam melaksanakan programnya sesuai dengan ketentuanketentuan yang telah disepakati bersama. Sistem pengawasan di MI Darussalam Pacet adalah dengan penentuan standar, supervisi kegiatan, pemeriksaan dan perbandingan hasil dengan standar serta kegiatan mengoreksi kegiatan atau standar.

Hambatan dan solusinya Manajemen perilaku organisasi madrasah pada MI tahun $2017 / 2018$.

Hambatan Pelaksanaan Managemen perilaku organisasi madrasah pada MI tahun 2017/2018. MI , dalam hal ini berdasarkan hasil wawancara yang telah lakukan dengan kepala sekolah baik secara formal maupun tidak formal, bahwa yang terlibat langsung dalam pengelolaan dan perencanaan adalah Kepala sekolah, guru serta bendahara sekolah. Dalam membuat perencanaan di MI Darussalam Pacet yang dilakukan selama ini dengan cara analisis volume dan beban pekerjaan yang dalam istilah lain disebut Tupoksi (Tujuan pokok dan fungsi) baru kemudian mencari personil yang tepat untuk mengisi posisi atau jabatan dengan berbagai macam pertimbangan.

Solusi Pelaksanaan Managemen perilaku organisasi madrasah pada MI tahun 2017/2018.

Solusi dalam pelaksanaan Manajemen perilaku organisasi madrasah pada MI tahun 2017/2018, maka perlu :

Mengadakan pengumuman rekrutmen tenaga pengajar yang sesuai formasi yang dibutuhkan dengan memperhatikan kualifikasi akademik dan non akademik. Melaksanakan rekrutmen dan seleksi terhadap calon guru atau karyawan dengan mendasarkan pada pertimbangan prestasi akademik, non akademik, pengalaman kerja, berakhlak baik diharapkanakan terpilih tenaga tenaga guru atau karyawan yang benar benar professional dan proporsional. Sistem

Penempatan dengan berprinsip“The rightman inthe rightplace" maka akan berdampak positif, yaitu dalam kinerja para pegawai akan terlaksana secara maksimal karena sesuai dengan minat, bakat, kapasitas dan kapabilitasnya sehingga dapat meningkatkan efektifitas dan efisiensi kerja. 
Melakukan pemetakan dan penerimaan guru yang sudah berkualifikasi atau lulusan pendidikan guru.

Melakukan pengembangan pada guru dengan mengikutkan dan mengadakan pelatihan, worshop dan lain sebagainya, Manajemen pelatihan dan pengembangan yang dilakukan dengan dua model, yakni onthe jobtraining dan ofthe jobtraining terlaksana dengan baik. Pelatihan dan pengembangan yang dilaksanakan diharapkan tidak hanya sebagai tolok ukur keberhasilan atau kegagalan suatu kegiatansaja,akantetapibenar-benarmembawa dampak positif yaitu adanya peningkatan kualitas SDM setelah mengikuti pelatihan tersebut, dengan kata lain harus ada actionplan atau Follow up (tindak lanjut) karya nyata dari hasil pelatihannya.

\section{KESIMPULAN}

Secara umum perencanaan SDM ini dilaksanakan dengan melakukan analisis terhadap seluruh kegiatan atau beban pekerjaan yang harus dilakukan oleh semua komponen sekolah. Hasil analisis dituangkan dalam Tupoksi (Tujuan Pokok dan Fungsi) yang dalam istilah manajemen merupakan penjabaran analisis jabatan dan deskripsi jabatan atau pekerjaan.

Berdasarkan hasil analisis jabatan atau pekerjaan ini dilakukan pengisian dan penempatan personil dalam jabatan sesuai dengan kapasitas intelektual, kapabilitas, pengalaman kerja dan ketauladanan. Pola yang dikembangkan dalam upaya melakukan penarikan dan seleksi terhadap calon tenaga pengajar dilaksanakan dengan mendasarkan pada pertimbangan prestasi akademik, non akademik, berakhlak baik, dan mengesampingkan hubungan kekrabatan atau dengan kata lain lebih mengutamakann prestasi dan profesionalisme ketimbang koncoisme.

Terkait dengan pelatihan dan pengembangan SDM yang selama ini dilakukan, evaluasi yang dilakukan masih cenderung pada pengukuran keberhasilan dan kegagalan pelatihan dari segi pelaksanaan, bukan berorientasi pada apakah secara efektif pelatihan yang dilaksanakan itu mampu mengubah perilaku dan apabila terjadi perubahan perilaku dan adanya peningkatan, apakah benar benar disebabkan karena pelatihan yang diikuti. Meskipun evaluasi yang selama ini dilakukan dengan menggunakan tiga tahap yaitu; (1) evaluasi bulanan, (2) evaluasi tengah semester, (3) evaluasi akhir tahun, tetapi masih ada ketimpangan terhadap perjalanan perjalanan dan pelaksanaan program itu sendiri. Hal ini mengakibatkanTupoksi sebagai standar pekerjaan yang digunakan sebagai tolok ukur keberhasilan dan kegagalan seorang guru melakukan tugas pekerjaan yang menjadi tanggung jawabnyya terabaikan.

Dengan dukungan pembinaan Kepala Madrasah kepadaguru dan karyawan, kerjasama Kepala Madrasah, guru, karyawan dan simpati masyarakat. Kegiatan-kegiatan masyarakat yang mendukung kegiatan pendidikan

\section{REFERENSI}

A.F. Stoner James, DKK, 1996, Manajemen, Edisi Indonesia, Penerbit PT. Prenhallindo, Jakarta A.M. Sardiman, 2001. Interaksi dan Motivasi Belajar Mengajar. Jakarta: Raja Grafindo Persada. Akdon; Hikmah. 2011. Manajemen Pendidikan .Bandung: Pustaka Setia

Ali Muhammad Taufiq. 2011. Praktik Manajemen Berbasis Al. Jakarta: Gema Insani.

Allen, Louis.1958. A Management and Organization. New York: Mc Graw-Hill Book Company

Allport (1954). The Struturing of Events: Outline of a General Theory With Applications to

Psychology (1954), artikel yang dimuat dalam Psychological Review 61: hal. 281-303.

Arikunto, Suharsimi. (1998). Prosedur penelitian; suatu pendekatan praktek. Jakarta: RinekaCipta.

Barnard, I, Chester. 1992. Organisasi dan manajemen, Struktur, Perilaku dan proses. Jakarta: Gramedi 
Depdikbud. Kamus Besar Bahasa Indonesia,Jakarta: Balai Pustaka, 1996

Fathoni Abdurahmat. 2006. Manajemen Sumber Daya Manusia. Bandung. Rineka Cipta.

Follett, Mary Parker. (1999). Visionary Leadership and Strategic Management.

MCBUniversityPress. Women in Management ReviewVolume 14 .Number 7.

Hariandja. 2002. Manajemen Sumber Daya manusia. Jakarta. Grasindo.

Hasibuan, Malayu. S. P. 2003. Manajemen Sumber Daya Manusia. Edisi

Revisi.BumiAksara.Jakarta

2004. Manajemen, Dasar, Pengertian dan Masalah. PT Bumi Aksara: Jakarta.

John M. Echols, Hasan Shadili, An English-Indonesian Jakarta: Gramedia,1996), 72.

John M. P fiffner, Frank P.Sherwood. Administrative Organization. Englewood Cliffs, NJ (1960)

Kusmiyadi dan Desminiarti (1991) Dasar-dasar perilaku.Yogyakarta.Puataka pelajar.

Kwick, Robert(1974) dalam Notoatmodjo, Soekidjo. 2003, Pendidikan Dan Perilaku Kesehatan, RinekaCipta, Jakarta.

Marimba Ahmad D. 1989. Pengantar Filsafat Pendidikan Islam. Bandung: Al-ma’arif.

Mathis Robert L dan Jackson John H. 2002.Human Resoursce Management, Alih Bahasa. Jakarta: Salemba Empat.

Miles, M.B.\& Huberman, A.M. 1994. Expended Source Book: Quality Data Analysis. London; sage publication.

Moleong, Lexy J. 2008. Metodologi Penelitian Kualitatif. Bandung: Rosdakarya . 2007.

Metodelogi Penelitian Kualitatif. Jakarta: PT. Remaja Rosdakarya

.(1991). Metodologi Penelitian Kualitatif. Bandung: PT. Remaja Rosdakarya

Mooney, D, James. Konsep Pengenbangan Organisasi Publik. 1996. Bandung: Sinar Baru Algesindo.

Muhibbin Syah. 2010. Psikologi Pendidikan dengan pendekatan baru. Bandung: PT Remaja Rosdakarya

Ma`arif, M. A., \& Rusydi, I. (2020). IMPLEMENTASI PENDIDIKAN HOLISTIK DI PONDOK PESANTREN AMANATUL UMMAH MOJOKERTO. EDUKASI: Jurnal Penelitian Pendidikan Agama Dan Keagamaan, 18(1), Article 1. https://doi.org/10.32729/edukasi.v18i1.598

Maarif, M. A., \& Rofiq, M. H. (2018). Pola Pengembangan Kurikulum Pendidikan Pesantren Berkarakter: Studi Implementasi Pendidikan Berkarakter di Pondok Pesantren Nurul Ummah Mojokerto. 13, 16

Nasrun Harahap. (1994). Penilaian Hasil Belajar. Surabaya: Usaha Nasional. Notoatmodjo, Soekidjo. 2003. Pengantar Pendidikan Kesehatan Dan Ilmu Perilaku Kesehatan. EdisiI, Andi Offset, Yogjakart

2007. Promosi Kesehatan dan Ilmu Perilaku. Jakarta: Rineka Cipta.

Penelitian oleh Admad Farozi pada tahun 2011 dengan judul Manajemen Sumber

Daya Manusia Dalam Peningkatan Mutu Sekolah Di SMA Negeri 2 Sragen

Penelitian oleh Siti Muslimah pada tahun 2014 dengan judul Manajemen Sumber Daya manusia dalam peningkatan mutu pembelajaran sekolah di SD Muhammadiyah plus Malang jiwan Colomadu.

Penelitian oleh Syahroni pada tahun 2007 dengan judul Perilaku organisasi dan manajemen mutu dalam upaya peningkatan prestasi di SMP Negeri 1 Brebes.

Robbins dan Judge.2008. Perilaku Organisasi, Edisi Duabelas, Penerbit Salemba Empat: Jakarta.

Rohmat. 2010. Modul Manajemen Mutu Terpadu. Surakarta.

2012. Pilar Peningkatan Mutu pendidikan. Cipta Media. Yogyakarta

. 2017. Manajemen Pembelajaran. Sukoharjo: Taujih

. 2017. Proses Mengajar Belajar Berkualitas Perspektif Pendidikan Islam Pengawal Pancasila. Gerbang Media: Yogyakarta

Rusyam, A. Tabrani. 1991. Kemampuan Dasar Guru Dalam Proses Belajar Mengajar. Bandung: Remaja Rosdakarya. 
Sarwono, S.W. Psikologi remaja. Edisi revisi 8. Jakarta: Raja Grafindo Pustaka, 2004.

Skinner, B.F. Scienceand Human Behavior. New York: FreePress. 1953. Sonny Sumarsono. 2003.

Manajemen Koperasi. Graha Ilmu, Yogyakarta. Sugiyono

2013. Statistika Untuk Penelitian. Bandung: CV. Alfabeta

Sumadi Suryabrata, 1998. Psikologi Pendidikan. Jakarta: PT. Raja Grafindo Persada.

Tim Penyusun. 2004. Pedoman Tesis dan Disertasi UNY. Yogyakarta: UNY Undang-Undang

Sistem pendidikan Nasional No. 20 tahun 2003

Wibowo. 2007. Manajemen Kinerja, Edisi Kedua, Penerbit Raja Grafindo Persada.

WS. Winkel (1996). Psikologi Pendidikan dan Evaluasi Belajar. Jakarta: PT Gramedia, cet ke-4 